doi:10.5559/di.23.1.10

\section{Julian McDougall MEDIA STUDIES - THE BASICS}

Routledge, Taylor \& Francis Group, London and New York, 2012., 214 str.

Dr. Julian McDougall profesor je u Centru za razvojna i primijenjena istraživanja na području obrazovanja na Sveučilištu u Wolverhamptonu u Engleskoj. Urednik je časopisa Media Education Research Journal, autor je brojnih udžbenika, poput: The Media Teacher's Book, Studying Videogames and After the Media: Culture and Identity in the 21st Century.

Tehnološki napredak doveo je do velikih pomaka $\mathrm{u}$ zadnje vrijeme $\mathrm{u}$ tome što čini medije, a to dovodi do novih teorija, koncepata i praksi u proučavanju medija. Akademski pristupi medijskoj globalizaciji idu dalje od "globalnoga sela", istražujući ulogu koju mediji imaju u miješanju lokalnih, nacionalnih i internacionalnih identiteta.

Samim time što živimo u suvremenom svijetu, svi aktivno odgovaramo medijima - nikad ih ne primamo bez neke misli ili interpretacije, odnosno tumačenja.

Media Studies - the basics jest vodič kroz promjenjivo društvo i postavlja temeljna pitanja:

1. Tko ili što su mediji?

2. Koji su ključni pojmovi i koncepti u analiziranju medija?

3. Koji su učinci globalizacije medija?

4. Kako izgledaju mediji u 21. stoljeću?
Knjiga je uvod u medijske studije danas te sadrži suvremene studije iz cijeloga svijeta, pojmovnik i upute za daljnje čitanje koje se nalaze na kraju svakoga, od ukupno šest poglavlja. Namijenjena je širokom krugu čitatelja - od studenata, učitelja, roditelja te onih čija stručna znanja obuhvaćaju velik broj tematskih područja. Poglavlja ove knjige raspoređena su na šire tematske linije, a svako započinje skupom ključnih ciljeva za razumijevanje. U uvodnom dijelu autor daje kratak osvrt na povijest medija. U prvom razdoblju - od 1960-ih do 1980-ih godina - opće je prihvaćeno da mediji, poglavito masovni mediji poput televizije, negativno utječu na ljude, pa je cilj izučavanja medija bio pomoći ljudima da se odupru tom utjecaju. U drugom razdoblju - od 1990-ih i u prvoj polovici 21. stoljeća - medijska kultura zakoračila je u razdoblje digitalne kreativnosti, koristeći se pristupačnom i dostupnom tehnologijom. Treće razdoblje, gdje smo i sada, sadrži svojstva prethodnih dvaju razdoblja, s jednom bitnom promjenom - internetom pa ga i nazivamo dobom interneta. Ciljevi prvoga poglavlja Studying $\mathrm{Me}$ dia (Izučavanje medija - Zašto, Što, Kako i Tko) jesu upoznati čitatelja s velikim rasponom pristupa proučavanju medija te povijesti medija i medijske kulture. Zanimljivo je da autor medije dovodi u vezu s popularnom kulturom, koja se danas može proučavati zahvaljujući medijskoj kulturi. Ona, za razliku od "visoke kulture" (književnost, klasična glazba, kazalište, fina umjetnost), nema "kanon", odnosno set velikih djela, pa ju je teže uvrstiti u kurikul. Uvriježeno je mišljenje da popularna kultura služi samo zabavi, a obrazovanje i zabava međusobno se isključuju. Ako je nešto tako utjecajno i moćno kao mediji, onda je važno znati kako funkcioniraju i djeluju, smatra dr. McDougall. Medijska kultura obuhvaća vezu između ljudi, medija, života i društva. Unutar teksta autor ubacuje citate i drugih autora, što čitatelju daje uvid u poglede i razmišljanja o medijima. Zamjetna se promjena vidi u kratkom razdoblju od sredine 1990-ih godina do 
STR. 201-204

2011. godine, kada dolazi do pojave Weba 2.0 na internetu kao novoga medija koji nam omogućuje stvaranje medija za nas same, gdje možemo dijeliti, sudjelovati, stvarati i uzajamno djelovati kao aktivni korisnici medija. Naglasak nije samo na razlikovanju svakodnevnoga medijskog angažmana nego i na razvoju kritičke medijske pismenosti. Ona, po autorovu mišljenju, ne podrazumijeva samo sposobnost upotrebe velikoga broja medija i mogućnosti razumijevanja primljene informacije nego i njezino propitkivanje, analiziranje te vrednovanje. Važno je znati i koje kompanije i korporacije proizvode medije koje pratimo te tko posjeduje te kompanije. Moć medija uvelike se ogleda u ekonomiji medija, pri čemu najviše profitiraju vlasnici najmoćnijih kompanija, poput Microsofta, Googlea i Time Warnera. Zaključno, digitalna tehnologija ima veliku ulogu u povezivanju ljudi i medija te usprkos velikim promjenama $\mathrm{u}$ pristupu medijima, manji broj velikih, višenacionalnih korporacija posjeduje medije, pa oni koji ih proučavaju moraju analizirati kako to djeluje na moć, informacije i utjecaj u suvremenom društvu. Proučavanje medija ubuduće bi trebalo potaknuti kreativno razmišljanje i kreativno djelovanje. U sljedećem poglavlju pod nazivom Reading Media, Doing Textual Analysis (Čitanje medija i tekstualna analiza) prikazuju se mikrotekstualne analize fotografija i pokretnih slika, odnosno filma, te novi konceptualni modeli dekonstrukcije suvremenih medijskih formi. Mikrotekstualna analiza odnosi se na proučavanje posebnih elemenata medijskoga teksta koji se mogu dekonstruirati samo pažljivim čitanjem. Medijski je tekst kombinacija raznih znakova, pa autor ovo poglavlje započinje semiotikom i vrstama znakova. Na primjeru fotografije dječaka u nogometnom klubu Barcelone približava čitatelju analiziranje medijskoga teksta, dok za pokretne slike navodi brojne primjere filmova i njegovih dijelova; položaja kamere, zvuka, montaže i scenografije. Nakon toga obrazloženi su sljedeći ključni pojmovi: žanr, prikazivanje i pripovijedanje. Dolazimo do zaključka da se isti tekst može promatrati iz različitih teorijskih perspektiva, pa se, primjerice, film može gledati kao proizvod određenog autora, zvijezde ili žanra. Ovo bi poglavlje kao zasebna cjelina moglo biti zanimljivo i korisno ljubiteljima fotografije i filma. Treće nas poglavlje - Powerful Media, People, Politics and Democracy (Moćni mediji, ljudi, politika i demokracija) - upoznaje s ulogom medija u demokratskom društvu, kritičkom analizom načina izražavanja moći medija, moći vlasništva i reguliranja medija te vezom između medija i politike. Povezanost medija i moći u društvu može se promatrati s mnogih gledišta, pa si svatko tko kritički razmišlja o medijima treba postaviti sljedeća pitanja: posjeduju li moćnici medije i koriste li se njima kako bi utjecali na nas? Podupiru li se međusobno vlasnici medija? Kakvu korist imaju političari od medija? Koliko je medijska slika danas važna političarima? Tu su i pitanja regulacije - tko ima pravo odlučivati kojim medijima možemo, a kojima ne možemo, imati pristup? Autor tvrdi da utjecaj medija vidimo $\mathrm{u}$ komercijalizaciji djetinjstva $\mathrm{kroz}$ medijsko oglašavanje te u nejednakosti spolova kroz desetljeća prikazivanja žena kao seksualnih objekata. U poglavlju su dana mnoga razmišljanja o navedenim temama i gledišta drugih teoretičara i autora te brojni primjeri osoba koje danas imaju moć i utjecaj na druge kroz medije; od pjevačice Lady Gage, Simona Cowella - vlasnika i tvorca popularnog X Factora, Juliana Assangea kao tvorca Wikileaksa te Australca, Ruperta Murdocha, vlasnika brojnih medija, poput filmskoga diva 21th Century Fox, kanala National Geographic, internetske stranice MySpace te brojnih drugih. Primjeri su suvremeni i čitatelja ne ostavljaju 
ravnodušnim, navodeći ga doista na kritička promišljanja o događajima u svijetu koji nas okružuje, što je i prvotni cilj ove knjige. Autor u mnogim podnaslovima prikazuje i opisuje ključne teorijske ideje i analize važne za proučavanje moći: Marksizam, kulturalni imperijalizam, političku ekonomiju, feminizam, postmodernizam, kao i najnoviju ideju Politike 2.0, ne ulazeći u detaljne rasprave i nametanje vlastita stava kako bi u čitatelju probudio interes za pojedino područje. On nas samo uvodi u šira tematska područja, dajući nam osnovu i temelj za daljnja čitanja, analize i promišljanja, kako bismo od pasivnih postali aktivni konzumenti medija. Kao važnu i zanimljivu ideju ovoga poglavlja izdvojili bismo pet pitanja britanskoga političara Tonyja Benna koja navodi autor, a koja bismo trebali postaviti svakomu na vlasti: Kakvu moć imate? Kako ste došli do nje? Za čiji je interes upotrebljavate? Komu ste odgovorni? Kako ćemo vas se riješiti? Na kraju poglavlja dolazimo do zaključka da je medijska stvarnost ili virtualno iskustvo nova stvarnost, a u demokratskom društvu građani imaju pravo na slobodne medije sa slobodnim pristupom i nepristranim informacijama, što medijski analitičari rijetko pronalaze u praksi. Ciljevi su četvrtoga poglavlja pod nazivom Global Media (Globalni mediji) prikazivanje internacionalnih pristupa $\mathrm{u}$ proučavanju medija, teorija globalizacije i globalnih medija, uloge socijalnih medija u stvaranju "globalnoga sela" te Kube kao primjera za bogatu internacionalnu/globalnu medijsku analizu. Autor se dosta detaljno uz brojne primjere bavi pojmom globalizacije te upotrebljava i termin glokalizacije, spajajući riječi globalno i lokalno. Po njegovu mišljenju, teorije kulturnog imperijalizma prikazuju Ameriku kao svemoćnu silu koja svoje vrijednosti širi po cijelom planetu, što dovodi do ideje tzv. McWorlda (McDonaldsova svijeta). Pozitivna strana globalizacije jest razvoj kulturnih različitosti stvaranjem kulturne hibridnosti te glokalnih medija, pri čemu dolazi do miješanja kulturnih stilova, lokalnog i globalnog, što postaje kozmopolitsko. Globalizacija se ne može odvijati ako ljudi ne postaju sve svjesniji globalne kulture, što se događa kroz medije, pa je ona veća što su ljudi izloženiji medijima koji ne potječu iz njihove zemlje. Dr. McDougall nas potiče da izbjegavamo generaliziranje i pojednostavnjivanje govoreći o globalnim medijima. Primjer takva jednostavnog pristupa bila bi izjava da globalni mediji dominiraju našim životima preko moćnih korporacija koje svoje medijske proizvode distribuiraju širom svijeta. Postoje mnoge zemlje gdje je globalni pristup ograničen bilo iz političkih, ekonomskih ili kulturnih razloga. Kuba je svakako primjer takve zemlje, gdje pristup internetu kao globalnom mediju ograničuje vlada. Kada govorimo o globalnom djetinjstvu, ipak je zastupljeniji medij televizija, a ne internet, kako navodi autor. Pita se je li globalna kultura neutralna i internacionalna ili proizlazi iz američkih vrijednosti. Postoje argumenti o štetnosti televizije kod djece, ali i oni o njezinoj edukativnoj vrijednosti, pa tako neki upotrebu interneta smatraju većim problemom, dok drugima - za razliku od televizije - on omogućuje interaktivno oslobođenje od pasivne upotrebe medija. Svjedoci smo globalizacije medija i njezine uloge $\mathrm{u}$ borbi za ljudska prava, primjer čega pronalazimo $\mathrm{u}$ Arapskom proljeću, dok s druge strane jednostavne procjene o tehnologiji i globalnim medijima treba izbjegavati, čemu u prilog ide i činjenica da većina svjetske populacije nema pristup internetu. Predzadnje nas poglavlje Changing Media (Mijenjanje medija), upoznaje $s$ važnim teorijama promjena za kritičko promišljanje, idejom da Web 2.0 čini Media Studies 2.0 nužnim te pogledima kako bi proučavanje medija moglo izgledati "nakon medija". 
DRUŠ. ISTRAŽ. ZAGREB

GOD. 23 (2014),

BR. 1

STR. 201-204

Upotreba medija poprilično se razlikuje između današnjih tinejdžera i onih prije petnaest godina. Jasno je, kako tvrde autori Fraser i Wardle, da medijsko obrazovanje mora pratiti promjene, zadržavajući pritom kritički stav o njihovu utjecaju. Potrebno je imati i usklađene poglede na budućnost - Media 3.0 i dalje. Svakako treba izbjegavati dvojne suprotnosti i pretpostavke, primjerice, o novim i starim medijima, jer se navedeni primjeri ubrzo zamjenjuju novim otkrićima i tehnologijama, pa moramo pronaći vlastiti srednji put, odnosno negdje između dviju krajnosti, savjetuje autor. Promjene medija možemo promatrati dvojako; kao mijenjanje samih medija i kao promjene kojima mediji utječu na društvo. U poglavlju se govori i o građanskom novinarstvu te blogovima kao dijelovima Weba 2.0. Zanimljiva je autorova usporedba interneta kao svjetskoga najvećeg kafića, odnosno virtualnoga prostora, u kojem se svake sekunde stvara novi blog. Posebno treba istaknuti dio u kojem autor govori o sreći korisnika medija, pa umjesto da se zapitamo jesmo li uključeniji, povezaniji i informiraniji građani u doba interneta, upućuje nas na to da se upitamo jesmo li sretniji što smo povezaniji s internetom? Gaunlett sreću povezuje s kvalitetom naših odnosa i povezanosti s drugim ljudima, a ne sa samopouzdanjem i radom. U zadnjem, šestom, poglavlju pod nazivom Making Media (Stvaranje medija) doznajemo tehničke i kreativne vještine koje Media Studies (Medijske studije) poučava. Ono povezuje teoriju i praksu usmjeravajući se na "glagole", odnosno radnje medija (zamišljanje, planiranje, govorenje, predstavljanje, dizajniranje, montiranje, teoretiziranje i učenje), koje su konstantne, za razliku od "imeni- ca" (software, hardware, tehnologija). Proučavanje medija nije samo kritičko promišljanje o medijima nego je i učenje. Medijska pismenost postiže se kombinacijom tehničkih, komunikacijskih, društvenih, građanskih vještina i kompetencija te kulturne svijesti i izražavanja. Knjiga je napisana kao cjelina, podijeljena je $\mathrm{u}$ šest poglavlja, ali svako se poglavlje može čitati zasebno kao manja samostalna cjelina. Autor se u knjizi često obraća kritičnim studentima medija, iako je ona namijenjena širem krugu čitatelja. U djelu Media Studies - the basics nalazi se šest fotografija $(\mathrm{u}$ svakom poglavlju po jedna), od kojih dvije autor pobliže analizira, dok ostale fotografije ne treba dodatno objašnjavati jer su jasne same po sebi i vežu se uz određeni tekst, pa čitatelju služe za vizualizaciju napisanoga. Glavni je cilj potaknuti čitatelja na aktivnu upotrebu medija i stvaranje kritičkoga stava prema njima i njihovu utjecaju na društvo. Nailazimo na mnogo zanimljivih primjera iz suvremenoga života, što olakšava povezivanje teorijskoga i praktičnoga dijela.

Ana Vukojević 